\title{
Ekonomik Büyümenin Belirleyicileri ve 2008 Krizi: Orta Asya Ülkeleri ve Türkiye Ekonomisi İçin Panel Veri Analizi ${ }^{1}$
}

\author{
Yrd. Doç. Dr. Mehmet MERCAN \\ Hakkari Üniversitesi, İ.̇.B.F., İktisat Bölümü, HAKKARI
}

\begin{abstract}
$\ddot{O Z Z E T}$
Bu çalı̧̧mada Orta Asya Ülkeleri (Azerbaycan, Kazakistan, Kırgızistan, Türkmenistan, Tacikistan ve Özbekistan) ve Türkiye örneğinde, ekonomik büyümenin belirleyicileri ve 2008 küresel ekonomik krizinin büyüme üzerindeki etkileri 1990-2012 dönemi verileri kullanılarak incelenmiştir. 2008 krizi, ABD'de ipotekli konut piyasasında 2006 yılı ortalarında başlamış, finansal piyasaları ve reel sektörü de etkilemis, Eylül 2008'den itibaren Avrupa Birliği (AB) ülkelerine ve dünyaya geneline yayılmış, dünya ekonomisinin \%2.3 oraninda küçülmesine yol açmış ve ülkelerin başta ekonomik büyüme olmak üzere makroekonomik dengelerini bozmuştur. Analiz sonucunda elde edilen ampirik bulgulara göre; ülkelerin ekonomik büyümelerine en çok katklyı sırasıyla; kamu harcamaları, ihracat ve özel tüketim harcamaları yapmıştır. Krizin ekonomik büyüme üzerindeki etkisi ise negatif ve istatistikî olarak anlamlı bulunmuştur.
\end{abstract}

Anahtar Kelimeler: Ekonomik Büyüme, 2008 Küresel Krizi, Orta Asya Ülkeleri, Panel Veri Analizi.

Jel Siniflamast: E21, E44, G01.

The Determinats of Economic Growth and 2008 Crisis: Panel Data Analysis for Central Asia Countries and Turkey's Economy

\section{ABSTRACT}

In this study the determinants of economic growth and the effects of 2008 global economic crisis on growth were analysed by using 1990-2012 periods' annual data in the sample of Turkey and Central Asia Countries (Azerbaijan, Kazakhstan, Kyrgyzstan, Turkmenistan, Tajikistan, and Uzbekistan). The 2008 crisis started in the USA in mid-2008 in mortgage markets and also affected the financial markets and the reel sector and it spread all over European Countries (EU) and the world from September 2008 and it caused a shrink in world economy by $2.3 \%$ and distorted the macroeconomic balances of countries including in particular the economic growth. According to the empirical findings of the analysis the government expenditures, the export and the private consumption expenditure in order made the most contribution to the countries' economic growth. Effect of the crisis on economic growth was negative and statistically significant. Analysis.

Key Words: Economic Growth, 2008 Global Crisis, Central Asia Countries, Panel Data

Jel Classification: E21, E44, G01.

1 Bu çalışma, Doğu Akdeniz Üniversitesi tarafından 24-26 Mayıs 2012 tarihleri arasında Gazimağusa/KKTC'de düzenlenen "13th International Conference on Econometrics, Operations Research, and Statistics" (ICEOS-2012) sempozyumunda "2008 Küresel Ekonomik Krizinin Türkiye ve Orta Asya Ülkelerinin Makroekonomik Değişkenlerine Etkileri: Panel Veri Analizi” başlığıyla sunulan çalışmanın düzenlenmiş ve büyük ölçüde genişletilmiş şeklidir. 


\section{GİRIŞ}

Dünyanın 1929 krizinden bu yana küresel ölçekte gördüğü en büyük kriz olan 2008 krizi, 2007 yılı Ağustos ayında finansal piyasalarda başlamış, büyük şok haline gelmiş, finansal sistem ve piyasalar üzerinde ağır hasara neden olmuştur (IMF, 2008). Hasar oldukça büyük olduğu için, ülkelerin çoğunda piyasa ekonomisi işlemesine rağmen ekonomi yönetimleri krizin etkilerini azaltmak amacıyla birçok banka ve finans kurumunu kamulaştırma yoluna gitmişlerdir. Özellikle ekonomisi gelişmiş olan ülkeler kapitalist düzenin en büyük bankacılık iflasıyla yüzleşmiştir ve pek çok devlet piyasa ekonomisi işleyişinin özüne aykırı olarak görülmemiş bir şekilde finansal sisteme müdahale etmiştir (Reinhart and Felton, 2009).

1929 y1lı krizi oldukça büyük ölçekte olmasına rağmen, piyasa ekonomisinin işlemediği ülkelerde krizden hiç etkilenmeme veya çok az etkilenme durumu olmuştur. Bu çerçevede 2008 krizi gerek günümüzde ülkelerin entegre olması dolayısıyla etkilediği ülkelerin çokluğu, gerekse kapitalist sistemin karşılaştı̆̆ ilk küresel kriz olması dolayısıyla diğerlerinden ayrılmaktadır.

Kapitalizmin bilimsel temellerinin kurucusu olarak bilinen Adam Smith, 1776 yılında yayınlamış olan ünlü "Ulusların Zenginliği” kitabında kapitalizmin kâr odaklı olduğu ve kârın genellikle, zengin ülkelerde düşük, fakir ülkelerde yüksek düzeyde gerçekleştiğini bu yüzden kârın en yüksek düzeyde gerçekleştiği ülkelerin krizden en fazla etkilenen ülkeler olduğunu belirtmiştir (Önder, 2009). Fakat küreselleşme sonucu ülkelerin entegre olmasıly 1990'lardan itibaren meydana gelen finansal krizler ise hem gelişmekte olan ülkelerde hem de gelişmiş ülkelerde büyük yıkımlara yol açmaktadır (Caramazza vd., 2000).

2008 küresel krizinin yayılması işsizlik ve büyüme gibi birçok makroekonomik değişkeni olumsuz etkilemiş, sadece iktisadi bir kavram olmaktan ziyade neoliberal muhafazakâr ideolojiyi sorgulanır hale getirmiştir. Kriz ve sonuçları göz önüne alındığı zaman, piyasa ekonomisinin tüm sorunlara çare oluşturabilen bir sistem olmadığı ifade edilebilir (Yeldan, 2008).

2008 ekonomik krizinin, temelinde tarihin en büyük konut ve kredi balonu vardır (Stiglitz, 2008, Öztürk ve Gövdere, 2011). 2007 yılı Ağustos ayında ABD'de ipotekli konut kredileri (mortgage) piyasalarında ortaya çıkan kriz, finansal kurumlar ve piyasaları derinden etkilemiştir (IMF, 2008). 2008 yılının ikinci yarısından itibaren ABD ve Avrupa'da finansal piyasaları etkileyen kriz finans temelli olmasının yanı sıra aynı zamanda bir reel sektör krizidir ve ilerleyen dönemlerde krizin reel sektör üzerindeki etkileri ortaya çıkmıştır (Hatipoğlu, 2011). ABD'de, bankalar tarafindan yanlış dağıtılan konut kredilerinin geri dönmemesi, konuta dayalı türev piyasalarında konutların gerçek değerinin çok üstünde işlem görmesi, denetim eksiklikleri krizin altyapısını hazırlamıştır ve öngörülemeyen sonuçlar ortaya çıkmıştır (Shiller, 2010, Tong and Wei, 2008).

Bankalar birincil piyasada mortgage kredileri vererek gayrimenkul üzerine ipotek konulduktan sonra, ikincil piyasalara menkul kıymet ihraç etmekte ve gayrimenkulün menkul kıymete dönüşme süreci bu şekilde işlemektedir 
(Krugman, 2010: 133-137). ABD'deki mortgage mortgage kredileri, ödeme şekli, faiz yapıs1, kredi talebinde bulunan kişinin durumuna göre; Prime ya da A kalite (üst gelir grubu), Alt A (orta gelir grubu) ve Subprime ya da riskli grup (alt gelir grubu) olmak üzere üç grupta incelenebilir ve risk durumuna göre uygun faiz oranı belirlenerek kredi verilir (Weaver, 2008: 22). 10 trilyon dolarlık hacmi olan ABD'deki mortgage piyasasında krediler üst gelir grubuna veriliyorken alt gelir grubuna da verilmeye başlanmış, denetim eksikliği sebebiyle konut kredilerini konut edinme yerine konut spekülatörlüğüne dönüşmesiyle sistemde sorunlar ortaya çıkmaya başlamıştır (Öztürk ve Gövdere, 2010). 2008 ortasında ABD'de alt gelir grubuna verilen mortgage kredilerinin hacmi 1.5 trilyon dolara yükselmiştir. 2000'li yıllarda, ABD'de faizler oldukça düşük olduğu için, alt gelir grubundaki kişiler çoğunlukla değişken faizli kredileri tercih etmiş, 2004'ten itibaren faizlerdeki oynaklık (FED'in faiz oranlarını arttırması) ve konut fiyatlarının düşmesiyle, bu kişiler aldıkları kredileri geri ödeyememeye başlamışlardır (Eğilmez, 2009: 66).

Kriz sürecinde işsizlik oranlarının artması, toplam talebin azalması, yatırım planlarının ertelenmesi, dış talepteki azalmaya bağlı olarak ihracatın düşmesi, döviz kuru dengesizlikleri ve ekonomilerin resesyona girmesi ya da negatif büyümeleri görülmektedir (IMF, 2009). Ulus ekonomileri krizle birlikte ortaya çıkan ekonomik ve sosyal çöküşleri engelleyebilmek için finans kurumlarını kurtarma, kamulaştırma ya da destekleme, vergileri azaltarak toplam talebi uyarma ve kamu harcamalarını arttırma gibi Keynesyen politikalar izlemişlerdir.

2008 küresel krizinin üzerinden 4 yıl geçmesine rağmen, 2012 Aralık ayında Avrupa Birliği (AB) Dönem Başkanı olan Kıbrıs Rum Yönetimi'nin İzlanda, İrlanda, Yunanistan, Portekiz, İspanya'nın ardından iflasını açıklaması, 17 milyar Euro'luk borcu için IMF, AB ve Dünya Bankası'ndan oluşan Troyka'dan yardım talep etmesi (www.cnnturk.com) ve AB'nin en güçlü ekonomilerinden Almanya'nın büyüme oranını aşağı yönlü revize etmesi krizin etkilerinin hala devam ettiğine dair bir kanıt sayılabilir.

Türkiye Ekonomisi'nin ihracatında önemli paya sahip olan $A B$ ülkelerinde devam eden ekonomik sorunların ülkemizi etkilememesi düşünülemez. Bu çalışmanın amacı; ekonomik büyümenin belirleyicileri ve 2008 küresel ekonomik krizinin, ülkelerin ekonomik büyümeleri üzerindeki etkilerini, krizden etkilendiği düşünülen 6 Orta Asya ülkesi ve Türkiye'nin, 1990-2012 dönemi verilerini kullanarak, panel veri analizi yöntemiyle incelemektir. Çalışmada girişi takip eden ikinci bölümde; krizlerin sınıflandırması yapılarak dünyada ve Türkiye'de meydana gelen krizler anlatılacak üçüncü bölümde; Orta Asya ilkelerinin ve Türkiye'nin makroekonomik durumları incelenecek dördüncü bölümde; krize ilişkin literatür özeti verilecektir. Ampirik analiz beşinci bölümde anlatılacak ve çalışma sonuç ve değerlendirme kısmı ile tamamlanacaktır. 


\section{KRIZLERIN SINIFLANDIRILMASI, DÜNYADAKİ VE TÜRKIYE'DEKİ KRİZLER}

Ekonomik krizleri temelde para ve bankacillk krizleri ya da finansal krizler olmak üzere iki grupta sınıflandırılabilir. Her iki krizin birlikte olması durumunda ikiz krizler olarak adlandırılmaktadır (Özatay, 2009: 17, Kaminsky, 2000). Bunun yanı sıra bazı çalışmalarda krizler dört başlık altında toplanmıştır; parasal krizleri, bankacılık krizleri, finansal krizler ve dış borç krizleri (Öztürk ve Gövdere, 2010).

Parasal krizler, dövize olan talebin spekülatif ataklar sonucu artmas1, ülkenin parasının değer kaybına uğraması durumunda ortaya çıkar. Dövize olan talebin artmasıyla döviz kuru aşırı yükselir ve bunun sonucunda döviz kuru rejimi çöker. Kısaca parasal krizler sonucu, Merkez Bankalarının döviz rezervlerinde yüksek düzeyde değer kayıpları ortaya çıkar ve bu durum sermaye hareketlerinde azalmalara yol açar. Sonuç olarak parasal krizler, ulusal paranın devalüasyonu olarak ifade edilebilir (Saxton, 2002).

Bankacılık alanında yeterli düzenlemelerin olmadığı durumda, bankacılık sektöründe meydana gelen yönetimsel problemler, iflaslar ve yükümlülüklerini yerine getirememe durumunda, hükümetler problemlerin çözümü için bankalara müdahale eder, (kurtarmak, kamulaştırma vb.) mevduat sahipleri bankacılık sistemine oluşan güvensizlik ortamı sonucu panikleyerek bankalardan paralarını çekmek isterler (bank-run). Bu süreçte, mevduat sahipleri yatırım aracı olarak, hisse senedi ve tahvillerin yerine altın, döviz gibi güvenilir araçları tercih ederler. Nitekim 2008 krizinin Amerika'da başlaması sonucu yatırımcılar dolar yerine güvenli liman olarak altını tercih etmiş, altının ons fiyatı kriz öncesi $635 \$$ iken 2012 yılında ortalama 1706\$'a yükselmiştir (www.dunya.com).

Finansal krizlerin ana sebebi, finans piyasalarında meydana gelen sorunlar sonucu finans kurumlarının batması ya da sermayelerinin önemli ölçüde azalmasıdır. Bunun sonucunda, reel ekonomi üzerinde büyük yıkıcı etkiler ortaya çıkabilir (Taylor, 2009). Finansal piyasaların liberalizasyonu finansal krizlerle ve bankacılık krizleri ile yakın ilişkilidir. Finansal liberalizasyonun olduğu ülkelerde bankacılık krizlerinin olma ihtimalini daha olasıdır (Demirgüç-Kunt and Detragiache: 1998). Dış borç krizleri, kamu borcunun ya da özel sektörün borcunun ödenememesi veya sürdürülememesidir (Öztürk ve Gövdere, 2010).

Dünya genelinde son yüzyıl düşünüldüğü zaman yaşanan en büyük kriz 1929 buhranıdır. Krizin etkileri on y1l boyunca devam etmiş, borsa çökmüş, fiyatlar \%25 düşmüş, işsizlik oranları on yıl sonra bile $\% 25$ düzeyinde seyretmiştir. Krizden dört yıl sonra bile GSMH 1929 yılındaki düzeyin \%65'ini yakalayabilmiştir (Galbraith, 2009: 177-190).

Özellikle 1990'lı yıllarda teknolojik gelişmelerle bilgiye hızlı ve ucuz erişilmesi, finansal piyasalarda risk ve getiri beklentilerine göre finansal ürünlerin çeşitlenmesini sağlamış, ayrıca ülkeler arası oluşan ekonomik entegrasyonlar, dış ticaretin ve sermaye hareketlerinin serbest hale gelmesiyle, özellikle büyük ekonomilerde meydana gelen ekonomik krizler, diğer ülkeleri kısa sürede etkiler hale gelmiştir (Eğilmez, 2009: 9, 53). Dünyada finans piyasalarındaki 
küreselleşme ve liberalizasyon sonucu, bilgi teknolojisindeki yenilikler sermaye hareketlerini arttırırken krizlerin yaygınlaşmasını ve hızlanmasını da sağlamıştır.

1990'll yıllardaki krizler genel olarak değerlendirildiği zaman; 1992-1993 Döviz Kuru Mekanizması (ERM) Krizi sıkı para politikalarından kaynaklanmış, $\mathrm{AB}$ ülkelerinde ortaya çıkmış bir parasal krizdir ve gelişmiş ülkelerde çıkan krizlere örnektir. Ekonomik denge içerinde tüketimin ya da yatırımların fazla olması da krizlere yol açabilir. Nitekim 1994-1995 Meksika krizi aşırı tüketim kaynaklı, 1997-1998 Asya krizi ise aşııı yatırım kaynaklıdır (Yay vd., 2001: 1530). Her üç kriz temel makroekonomik değişkenlerdeki sorunlardan değil, daha çok sabit, yarı-sabit ve ortak bir para birimine bağlı döviz kuru sistemlerinden, reel döviz kurundaki aşırı yükselmeden, uluslararası likidite yetersizliğinden ve yoğun sermaye hareketlerinden kaynaklanmıştır. Meksika ve Asya krizinde ayrıca bankacılık sektöründeki sorunlar önemli rol oynamıştır. 1999 Brezilya Krizinde ana sebep makroekonomik sorunlardır (Öztürk ve Gövdere, 2010).

1998 Rusya Krizi, yüksek bütçe açıkları, kur riski, yabancı kredilerde kısa vadeli borçların ağırlığı, finans sektöründe ve bankacılık sektöründe altyap1 ve denetimsel sorunlar, maaş ve ücret ödemelerinde bütçe disiplininin kaybolması ve sosyal güvenlik ödemelerine bağlı borçların artması, petrol ve gaz ürünlerinin fiyatlarında aşırı düşmeler sayılabilir. Aşırı değerli döviz kuru, Peso'nun ihracatta rekabet gücünü kaybetmesi, kamu harcamalarındaki artış, vergi gelirlerindeki düşüş ve yüksek oranda işsizlik oranlarının 1999 Arjantin Krizi'nin ana sebepleri olduğu söylenebilir (Hatipoğlu, 2011).

1990'lı yıllarda yaşanan krizler genel olarak değerlendirildiği zaman; krizlerin birçok ortak özelliği olmasının yanı sıra, krizlerin tamamen aynı özellikte olduğu ve tek faktörden kaynaklandığı söylenemez.

Türkiye'nin yaşadığı krizlere göz atacak olursak; 1994 krizi para krizi olup, Dolar/TL paritesinin bozulmasından kaynaklanmış, hazine içeride borçlanamaz duruma gelmiş, kredi derecelendirme kuruluşlarının kredi notunu düşürmesi sonucu, dışarıdan da kredi bulunamaz hale gelinmiştir. Bunun üzerine hükümet 5 Nisan 1994'te ekonomik istikrar programını uygulamaya koymuş, IMF ile bir stand-by anlaşması imzalamıştır (Özdemir ve Göçer, 2011). Bu krizde Avrupa para piyasalarındaki sorunlar ve spekülatif sermaye hareketleri etkendir.

1997 Asya ve 1998 Rusya krizlerinden etkilenen Türkiye ekonomisi yaşanan 1999 depremi ile birlikte sanayi tesislerinin önemli ölçüde zarar görmesiyle, 1999 yılında \%3,3 oranında küçülmüş, enflasyon \%70'i faizler \%100'ü aşmıştır. Ülkedeki siyasi ve ekonomik istikrarsızlık ortamı sonucunda sermaye çıkışları yaşanmış, döviz talebini arttırmış, uygulanmakta olan sabit kur rejimi sürdürülemez hale gelmiştir. Kasım 2000'de Demirbank merkezli bankacılık krizinin ortaya çıkması sonucunda bankaların bir kısmı Tasarruf Mevduatı Sigorta Fonuna devredilirken, bazıları da batmıştır. Bankacılık sektöründeki yolsuzluklar sonucu bireylerin tasarruflarını yastık altında tutmaları ve yurtdışına sermaye çıkışları sonucu piyasada TL sıkıntısı baş göstermiş ve faizler 21 Şubat 2001'de gecelik faiz \%6200 olmuştur (Eğilmez, 2009: 78). 
Merkez Bankası artan döviz kuru baskıları karşısında, 22 Şubat 2001'de sabit kur rejimini terk ederek, serbest kur rejimini uygulamaya koymuştur.

Türkiye'nin ihracatının önemli bir kısmının AB ülkelerine ve Amerika'ya bağlı olması sebebiyle krizdeki ülkelerin talebinin düşmesi sonucu 2008 krizi Türkiye'yi; ihracat kanalından etkilemiştir. İhracatın düşmesi sonucu üretim azalmış, ekonomi küçülmüş, firmaların hızla işçi çıkarması sonucu Şubat 2009'da işsizlik \%16,1'e yükselmiştir. Bu süreçte ihracat Mayıs 2009'da bir önceki yılın aynı dönemine oranla \% 41, 2009 sonunda 2008'e göre \% 23 oranında azalmıştır. Türkiye'nin krizin derinden etkilediği $\mathrm{AB}$ ülkelerine olan ihracatı $\%$ 25,9, OECD ülkelerine ise \% 23,1 oranında azalmıştır. Ekonomileri görece daha zayıf olan Karadeniz Ekonomik İşbirliği'ne bağlı ülkeler de krizden derinden etkilenmişler ve bu ülkelere Türkiye'nin yaptığı ihracat \% 41 oranında azalmıştır (Özdemir ve Göçer, 2011). 2008 küresel kriz tüm dünya ülkeleri gibi Türkiye'yi de derinden etkilemiştir. Bu süreçte Türkiye'nin Arap ve Afrika ülkeleri ile dış ticaretinin artması, ekonomi yönetiminin uyguladığı para ve maliye politikaları ve 2001 krizi tecrübesiyle bankacılık sisteminin güçlü olmasının krizin etkilerini azalttığı söylenebilir.

\section{ORTA ASYA ÜLKELERI VE TÜRKIYE'NIN MAKROEKONOMIK DURUMU}

Yaşanan 2008 ekonomik krizi, ülkelerin ekonomik büyümelerinden diş ticaretlerine, istihdam oranlarından cari açılarına, sermaye hareketlerinden borsalara kadar pek çok makroekonomik değişkeni üzerinde, önemli etkiler meydana getirmiştir. Tablo 1'de Orta Asya Ülkeleri'nin seçilmiş makroekonomik göstergeleri verilmiştir.

Tablo-1: Orta Asya ülkeleri ve Türkiye'nin Makroekonomik Göstergeleri*

\begin{tabular}{|c|c|c|c|c|c|c|c|c|}
\hline & $\begin{array}{c}\begin{array}{c}\text { Nüfus } \\
\text { (Milyo } \\
\text { n) }\end{array} \\
\end{array}$ & $\begin{array}{c}\text { Kişi Başı } \\
\text { Gelir(\$) }\end{array}$ & $\begin{array}{c}\text { GSYIH } \\
\text { (Milyar } \\
\$ \text { ) } \\
\end{array}$ & $\begin{array}{c}\text { GSYIH } \\
\text { Siralama } \\
\text { Sı } \\
\end{array}$ & $\begin{array}{c}\text { İhracat } \\
\text { (Milyar } \\
\$ \text { ) }\end{array}$ & \begin{tabular}{|c|} 
Ihracat \\
Siralama \\
sı \\
\end{tabular} & \begin{tabular}{|c|} 
Ithalat \\
(Milyar \\
$\$)$
\end{tabular} & \begin{tabular}{|c|} 
Ithalat \\
Siralama \\
sı \\
\end{tabular} \\
\hline Azerbaycan & 9.2 & 7164 & 66.6 & 64 & 35.7 & 57 & 17.0 & 76 \\
\hline Kazakistan & 16.7 & 12116 & 203.5 & 48 & 96.8 & 41 & 61.7 & 50 \\
\hline Kirgizistan & 5.5 & & 64 & 142 & 20 & 107 & 64 & 102 \\
\hline $\begin{array}{c}\text { Türkmenist } \\
\text { an }\end{array}$ & 5.1 & 6798 & 35.1 & 88 & 25.7 & 64 & 15.6 & 77 \\
\hline Tacikistan & 8.0 & 871 & 6.9 & 140 & 1.2 & 118 & 4.4 & 114 \\
\hline Özbekistan & 29.7 & 1717 & 51.1 & 72 & 14.2 & 71 & 15.2 & 78 \\
\hline Türkiye & 73.9 & 10666 & 789.2 & 17 & 208.6 & 30 & 249.0 & 23 \\
\hline
\end{tabular}

Kaynak: Dünya Bankası ve DPT verileri kullanılarak yazar tarafindan oluşturulmuştur.

*: 2012 yılı baz alınmıştır.

Tablo-1'de görüldüğü gibi, Orta Asya ülkeleri içerisinde ekonomik büyüklüğ̈̈ en fazla olan ülke Kazakistan'dır. Kazakistan 203.5 Milyar \$'lık büyüklüğü ile ekonomik büyüklük olarak dünya genelinde 48. siradadır. Kazakistan'1 66.6 Milyar\$'lık ekonomik büyüklüğ̈̈ ile Azerbaycan takip etmekte ve bu ülkenin ekonomisi dünyada 64. sıradadır. Özbekistan ekonomik büyüklük olarak 51.1 Milyar \$ ile 72. sırada, Türkmenistan 35.1 Milyar \$’lık büyüklük ile 
88. Sıradadır. Tacikistan ve Kırgızistan'ın ekonomik büyüklükleri 6.9 ve 6.4 Milyar \$ olup 140 ve 142. Siradadırlar. Orta Asya ülkelerinin toplam ekonomik büyüklüğüne bakıldığı zaman ise 369.6 Milyar\$'lık hacim söz konusudur. Kişi başı gelir göz önüne alınırsa, Kazakistan $12116 \$$ ve Azerbaycan $7164 \$$ gelir ile ilk siradadirlar.

Orta Asya ülkelerinin dış ticaret rakamları incelendiği zaman Kırgızistan Tacikistan ve Özbekistan açık vermekte, diğer ülkeler ise dış ticaret fazlası vermektedir. Diğer ülkelerin diş ticaret fazlası vermesinin ana sebebi sahip oldukları petrol ve doğalgaz gaz ihracatıdır. 2010 yılı göz önüne alınırsa Azerbaycan'ın mal ihracatının \% 87'sini petrol ve petrol ürünleri oluşturmakta, dış ticaretinin yarısını İtalya, Fransa ve İsrail'e yapmaktadır. Kazakistan'ın mal ihracatının \% 65'in ham petroldür. Ham petrol ve petrol ürünleri düşünülürse bu oran \% 71'e çıkmakta, ihracatının \% 42,2'sini Çin, İtalya ve Fransa'ya yapmaktadır. Kırgızistan'ın mal ihracatının \% 45'inin altından oluşturmakta ve İsviçre, Birleşik Arap Emirlikleri ve Rusya Federasyonu ile ağılıklı olarak ticaret yapmaktadır.

Tablo-2: Orta Asya ülkeleri ve Türkiye'nin Büyüme Rakamları

\begin{tabular}{|l|r|r|r|r|r|r|r|r|r|r|r|r|}
\hline & 2001 & 2002 & 2003 & 2004 & 2005 & 2006 & 2007 & 2008 & 2009 & 2010 & 2011 & 2012 \\
\hline Azerbaycan & 9,9 & 10,6 & 11,2 & 10,2 & 26,4 & 34,5 & 25,0 & 10,8 & 9,3 & 5,0 & 1,0 & 2,2 \\
\hline Kazakistan & 13,5 & 9,8 & 9,3 & 9,6 & 9,7 & 10,7 & 8,9 & 3,3 & 1,2 & 7,3 & 7,5 & 5,0 \\
\hline Kırgızistan & 5,3 & 0,0 & 7,0 & 7,0 & $-0,2$ & 3,1 & 8,5 & 8,4 & 2,9 & $-1,4$ & 7,0 & $-0,8$ \\
\hline Tacikistan & 10,2 & 9,1 & 10,2 & 10,6 & 10,5 & $-15,7$ & 21,7 & 21,2 & 3,9 & 6,5 & 7,4 & 7,5 \\
\hline Türkmenistan & 20,4 & 15,8 & 17,1 & 17,2 & 13,0 & 11,4 & 11,8 & 14,7 & 6,1 & 9,2 & 9,9 & 11,1 \\
\hline Özbekistan & 4,2 & 4,0 & 4,2 & 7,7 & 7,0 & 7,3 & 9,5 & 9,0 & 8,1 & 8,5 & 8,3 & 8,2 \\
\hline Türkiye & $-5,7$ & 6,2 & 5,3 & 9,4 & 8,4 & 6,9 & 4,7 & 0,7 & $-4,8$ & 9,2 & 8,5 & 2,2 \\
\hline
\end{tabular}

Kaynak: Dünya Bankası verileri kullanılarak yazar tarafindan oluşturulmuştur.

Orta Asya ülkeleri ve Türkiye'nin büyüme rakamları göz önüne alındığ1 zaman; 25 Mayıs 2005 Bakü-Ceyhan boru hattının açılması ve petrol ihracatı ile 2005-2007 döneminde \%28.6 gibi oldukça yüksek büyüme rakamlarını yakalayan Azerbaycan'in 2008'den itibaren büyümesi \%10.8'e düşmüş ve 2012 yıllnda \%2.2 olarak gerçekleşmiştir. Kazakistan 2008 krizine kadar \%8 civarında büyürken, 2008-2009 döneminde \%2.2 büyümüştür. Kırgızistan kriz öncesi 2007 ve 2008 'de $\% 8$ büyürken, 2009 y1lında bu rakam \%2.9 olmuş, 2010 y1lında ise negatif olarak gerçekleşmiştir.

Tacikistan 2007 ve 2008 'de \%21 gibi büyüme rakamı yakalamışken 2009'da bu rakam \%3.9'a düşmüştür. Türkmenistan 2001-2012 döneminde en düşük büyümeyi 2008 krizinden sonraki yıllarda yaşamıştır. Özbekistan ise kriz ile birlikte \%1'lik büyüme kaybı yaşamıştır. Kriz döneminde negatif büyüme Kırgızistan ve Türkiye'de gerçekleşmiştir. Kriz sonrası büyüme rakamları incelendiğinde ise en hızlı toparlanma Türkiye ekonomisinde gerçekleşmiş ve Çin'den sonra dünyada en hızlı büyüyen ülke olmuştur. 
Şekil-1: Orta Asya ülkeleri ve Türkiye'nin İşsizlik Rakamları

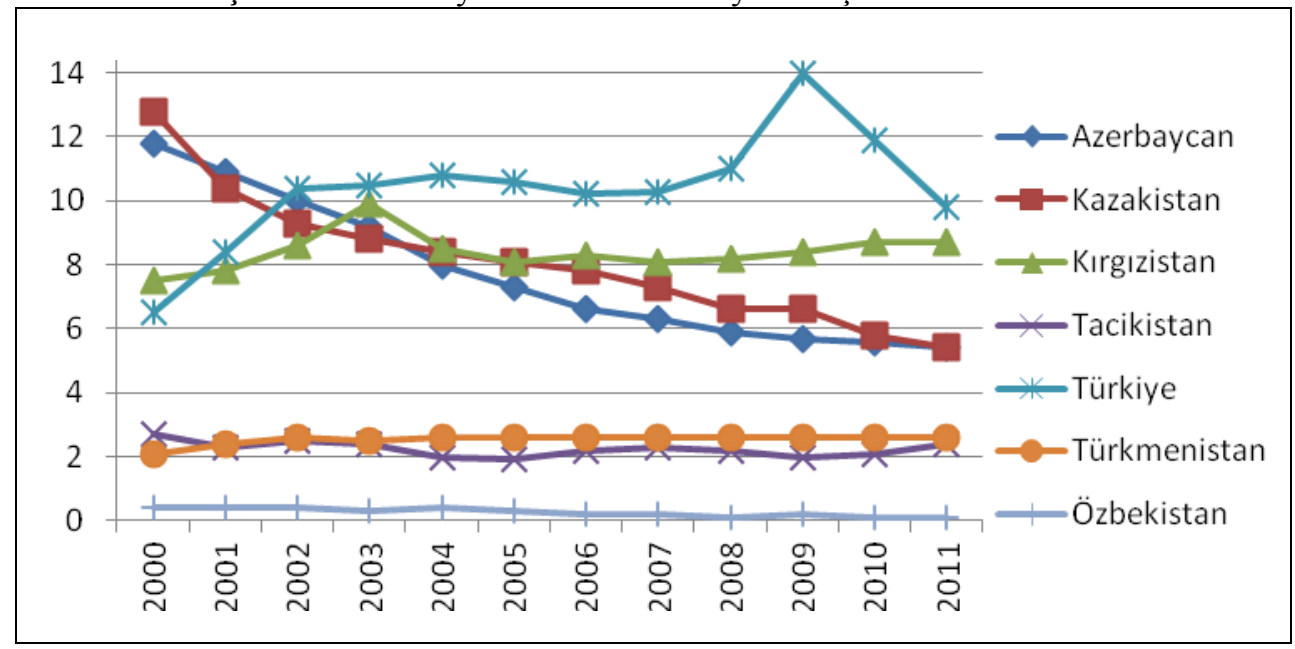

Kaynak: Dünya Bankası ve Asya Kalkınma Bankası.

Şekil 1 ve Tablo 3’ten izlenebileceği gibi, Orta Asya ülkeleri ve Türkiye'nin işsizlik oranları incelendiği zaman; Azerbaycan, Kazakistan, Türkmenistan ve Özbekistan da işsizlik sürekli azalmış 2008 krizinden etkilenmemiştir. Tacikistan, Türkmenistan ve Özbekistan'da işsizlik oranları $\% 5$ 'in altındadır. Orta Asya ülkeleri içerisinde 2008 krizi süresince işsizliğin arttığı ülke Kırgızistan ve Tacikistan'dır. Fakat işsizlik oranlarındaki artış oldukça düşük düzeydedir.

Tablo-3: Orta Asya ülkeleri ve Türkiye'nin İşsizlik Rakamları

\begin{tabular}{|l|l|l|l|l|l|l|l|l|l|l|l|l|}
\hline & 2001 & 2002 & 2003 & 2004 & 2005 & 2006 & 2007 & 2008 & 2009 & 2010 & 2011 & 2012 \\
\hline Azerbaycan & 10,9 & 10 & 9,2 & 8 & 7,3 & 6,6 & 6,3 & 5,9 & 5,7 & 5,6 & 5,4 & 5,1 \\
\hline Kazakistan & 10,4 & 9,3 & 8,8 & 8,4 & 8,1 & 7,8 & 7,3 & 6,6 & 6,6 & 5,8 & 5,4 & 5,3 \\
\hline Kırgizistan & 7,8 & 8,6 & 9,9 & 8,5 & 8,1 & 8,3 & 8,1 & 8,2 & 8,4 & 8,7 & 8,7 & 8,6 \\
\hline Tacikistan & 2,3 & 2,5 & 2,4 & 2 & 1,9 & 2,2 & 2,3 & 2,2 & 2 & 2,1 & 2,4 & 2,5 \\
\hline Türkmenistan* & 2,4 & 2,6 & 2,5 & 2,6 & 2,6 & 2,6 & 2,6 & 2,6 & 2,6 & 2,6 & 2,6 & 2,6 \\
\hline Özbekistan & 0,4 & 0,4 & 0,3 & 0,4 & 0,3 & 0,2 & 0,2 & 0,1 & 0,2 & 0,1 & 0,1 & 0,2 \\
\hline Türkiye & 8,4 & 10,4 & 10,5 & 10,8 & 10,6 & 10,2 & 10,3 & 11 & 14 & 11,9 & 9,8 & 9,1 \\
\hline
\end{tabular}

Kaynak: Dünya Bankası ve Asya Kalkınma Bankası. *: Türkmenistan'ın 2005'ten itibaren işsizlik rakamları mevcut değildir. Grafik çizebilmek için 2005 rakamları alınmıştır.

Şekil 1 ve Tablo 3'te görülebileceği gibi Türkiye'nin işgücü piyasası 2008 krizinden oldukça fazla etkilenmiş, Şubat 2009 'da \%16.1 ile en yüksek seviyeyi görmüştür. Kriz öncesi \%10 civarında olan işsizlik 2010 yılında \%14'e yükselmiştir. Türkiye'de işsizlik oranları ancak 2011 yılında 2008 krizi öncesi düzeye inebilmiştir. Türkiye enerjisini ithal eden ülkedir ve petrol ve doğal gaz açısından yeterli doğal kaynaklara sahip değildir. Bu yüzden kriz dönemlerinde 
işgücü piyasası zarar görmektedir. Orta Asya ülkelerinde ise ihracat petrol ve doğal gaza dayalı olduğu için krizlerden işgücü piyasası oldukça az etkilenmekte ya da etkilenmemektedir.

\section{LITERATÜR}

2008 küresel ekonomik krizine ilişkin literatür göz önüne alındığında; çalışmaların büyük çoğunluğu kriz öncesi ve sonrası durumlara ilişkin makroekonomik durumun özeti şeklindedir. Bazı çalışmalar kriz sinyallerinin öngörülebilmesi için yapılan ekonometrik analizlerdir. Ekonometrik çalışmalar genellikle krizin işsizlik ve ekonomik büyüme üzerindeki etkilerini analiz etmeye yöneliktir. Analizlerin bir bölümü krizleri kukla değişken olarak modele dahil etmiş ve makroekonomik değişkenler üzerindeki etkilerini incelemiştir.

Reinhart ve Rogoff (2008), farklı ülke örneklerinde 1899-2001 döneminde bankacılık sektöründe meydana gelen 14 büyük krizi, panel veri analiziyle incelemiştir. Analiz sonucunda; kriz sürecinde ülkelerin milli gelirlerinin \%9.3 azaldığını, işsizlik oranlarının \%7 arttığını ve krizlerin etki süresini yaklaşık 2 yıl olduğunu belirtmiştir. İşsizlik oranlarının krizlerden, diğer makroekonomik değişkenlere göre daha uzun süreli etkilendiğini, bu sürenin yaklaşık 4.8 yıl olduğunu bulmuştur.

Rose ve Spiegel (2009), 107 ülke için 2008 krizi MIMIC (Multiple Indicator Multiple Cause) modeli yardımıyla birçok makroekonomik değişkeni kullanarak yaptığ 1 analiz sonucunda krizin ilk sinyallerinin 2006 ve öncesinde olabileceğini ifade etmiştir.

Weeks (2009), 2008 krizinin ekonomik büyümeye etkisini, Sierra Leone örneğinde araştırmıştır. Analizde 2008 krizini kukla değişken olarak modellemiş ve krizin ekonomik büyümeyi olumsuz yönde etkilediğini ifade etmiştir. Ayrıca, ihracat ve kamu harcamalarının $\% 19$, ithalatın $\% 37$ düzeyinde büyümeyi etkilediği bulgusuna ulaşmıştır.

Özdemir ve Göçer (2011), Türkiye ekonomisi için 2008 krizinin makroekonomik değişkenler üzerindeki etkilerini, 1988-2011 dönemi aylık verileriyle, VAR analiziyle araştırmış ve krizin etkisinin yaklaşık iki yıl sürdüğ̈nü belirtmiştir.

Öztürk ve Gövdere (2011), küresel kriz sebeplerini, sonuçlarını ve Türkiye ekonomisine etkilerini incelediği çalışmasında, krizin diğer krizlerden farklı olarak, öncelikle likidite sıkışıklı̆ından kaynaklanmadığını, piyasalarda yeterli miktarda likiditenin var olduğunu, ancak paraya sahip olanların geri ödenmesi noktasında belirsizlik olanlara verme konusunda istekli davranmadıklarını ifade etmiştir. İkinci olarak, bu krizde gelir değil borç talep şokunu tetiklemiştir. Krizin doğrudan konut kredilerinden değil, buna yapılan işlem yapılan türev piyasalarından kaynaklandığını belirtmiştir. Türkiye'nin krizden ihracat kanalı yoluyla önemli ölçüde etkilendiğini belirtmiş ve ihracatta ülke çeşitliliğinin önemine vurgu yapmıştır.

Hatipler (2011), çalışmasında Türkiye'nin 2008 krizi ile mücadele kapsamında almış olduğu mali nitelikteki tedbirlerin, krizin Türkiye’yi az etkilemesinin sebebi olduğunu ifade etmiştir. Krizin büyüme hızlarında ve toplam 
talepte düşüşe neden olduğu, durgunluk ve enflasyonist eğilimlere yol açtığını belirtmiştir.

Ateş (2011), 2008 krizini uluslararası ilişkiler bağlamında irdelemiş, krizin durgunluğa yol açacağını, fakat kriz sonrası dönemde tekrar eskiye dönülebileceğini belirtmiş, kriz süreçlerinin küreselleşmeye ivme kazandırdığını belirtmiştir. 1929 krizinin 2. Dünya savaşını tetiklediğini fakat sonrasında GATT, DB, IMF, NATO vb. kurulmasıyla bütünleşmenin arttığını vurgulamıştır.

Gençtürk vd. (2011), Türkiye örneğinde 2008 krizinin etkilerini, BIST'de yer alan 77 firmanın finansman yapısı yönüyle incelemiştir. Kriz ile birlikte firmaların borç/sermaye oranının artış göstererek \%52'ye geldiği, kısa vadeli borç düzeyinin $\% 113$, uzun vadeli borç düzeyinin ise $\% 53$ arttı̆̆ını belirtmiştir.

Hepaktan ve Çınar (2011), 2008 krizinin Türkiye üzerindeki etkisini reel sektör yönüyle incelemiştir. Analizde, sanayi üretim endeksi, döviz kuru ve kriz kukla değişkeni yardımıyla incelemiştir. Analizde, kriz kuklasının ve döviz kurunun sanayi üretim endeksini negatif yönde etkilediğini belirtmiştir. Ayrıca döviz kurlarındaki artışların sanayi üretim endeksi üzerindeki etkisi oldukça yüksek düzeyde bulunmuştur.

Xu and Hamori (2012), 2004-2010 döneminde BRIC ülkeleri ve Amerika arasındaki hisse senedi fiyatları arasındaki dinamik ilişkileri incelemişlerdir. 2008 krizinin etkilerini izleyebilmek amacıyla Eylül 2008 yılını baz alarak iki dönem için yaptıkları çalışmada, kriz sebebiyle BRIC ve Amerika arasındaki hisse senedi fiyatları arası etkileşimin zayıfladığı bulgusuna ulaşmışlardır.

Furceri and Mourougane (2012), OECD ülkeleri için 1960-2008 dönemini kapsayan çalışmasında, krizin çıktı üzerindeki etkisinin kalıcı ve negatif olduğunu ve üretimi \% 1.5-2.4 aralığında düşürdüğünü belirtmiş, ekonomilerin yapısal özelliklerine göre etkilenme düzeyinin değişebileceğini ifade etmiştir.

Kavcioğlu (2012) çalışmasında, Türkiye'nin yaşadığ dönemlerde bankacılık sektörünün kredilerinin sektörel dağılımlarının ve sektörlerin büyümeye katkılarının analizlerini yapmıştır. Yazara göre; özellikle 2001 krizi sonrası bankacılık alanında yapılan düzenlemelerin 2008 krizinin etkilerinin azaltılmasına önemli katkılar sağladığ 1 ve kredi hacmi artışlarının büyümeyi desteklediğini belirtmiş̧ir. Ayrıca, 2010 yılında Türkiye ekonomisinin büyümesine katkıyı en fazla olan sektörlerin sırasıyla, imalat sanayi, toptan ve perakende ticaret, ulaştırma, haberleşme ve depolama hizmetleri ile inşaat sektörü olduğunu belirtmiştir.

Erol ve Özdemir (2012) çalışmasında, 2008 krizinin işgücü piyasaları üzerindeki etkilerini incelemiştir. Yazarlar, krizin en çok işgücü piyasasını etkilediğini ve bu etkilerin azaltılmasında alınan tedbirlerin gecikmiş olduğunu belirtmişlerdir. Ayrıca yazarlar, kriz süreçlerinde karar vericilerin aktif istihdam politikaları uygulamaları gerektiğini ve bu politikaların uygulanma sürecinde uygulanan politikaların sosyal etkilerinin de göz önünde tutulması gerektiğini belirtmişlerdir.

Deveci ve Değirmen (2013), çalışmasında; Amerika ve Türkiye örneğinde 2008 küresel kriz çerçevesinde ikiz açıklar ve kriz ilişkisini Granger nedensellik 
ve Johansen eşbütünleşme analizi ile incelemişlerdir. Analiz sonucunda; ikiz açıkların Amerikan ekonomisi üzerinde etkisi saptanırken, Türkiye ekonomisi için net bir sonuca ulaşılamamıştır.

\section{V.AMPIRIK ANALIZ}

\section{A. Veri Seti ve Model}

$\mathrm{Bu}$ çalışmada, krizden etkilendiği düşünülen altı Orta asya ülkesi ve Türkiye'ye ait, 1990-2012 dönemi, y1llık GSYİH $(Y)$, özel tüketim $(C)$, kamu harcamaları $(G)$, ihracat $(X)$ ve ithalat $(M)$ verileri kullanılmıştır. 2008 küresel ekonomi krizi, kukla değişkenle $(K)$ modele dâhil edilmiştir. Veriler, IMF ve UNCTAD'dan düzey değerleri olarak alınmıştır. Serilerin logaritmaları alınmış ve ithalat serisi negatif hale dönüştürülmüştür.

Analizde, Keynesyen milli gelir fonksiyonu temel alınarak, diğer değişkenlerin ekonomik büyüme üzerindeki etkileri belirlenmeye çalışılmıştır. Yani çalışmanın matematiksel modeli:

$Y=C+G+X-M$

Biçiminde olup, bu ifade ekonometrik modele dönüştürüldüğünde:

$Y_{t}=\alpha_{0}+\propto_{1} C_{t}+\propto_{3} G_{t}+\alpha_{4} X_{t}-\propto_{5} M_{t}+\propto_{6} K_{t}+u_{t}$

biçimindedir.

Analiz için Stata 11 ve EViews 5.1 ekonometrik analiz programlarından yararlanılmış olup, model seçimi ve doğrulama testleri (değişen varyans ve otokorelasyon) için kodlar ${ }^{2}$ kullanılmıştır.

\section{B. Yöntem}

Farklı ülkelere ait verileri bir arada inceleyebilmek için, panel veri analizi yöntemi kullanılmıştır. Panel veri analizi (Baltagi, 2001; Gujarati, 1999):

$$
Y_{i t}=\alpha+X_{i t}^{s} \beta+u_{i t}
$$

modelinde yer alan hata teriminin ( $u_{i t}$ ) bireysel ve zaman etkileri yönünden bileşenlerine ayrıştılmasına dayanmaktadır. Modelde $i$ ülkeleri, $t$ de zamanı göstermektedir. Hata terimi ayrıştırıldığında:

$$
u_{i t}=\mu_{i}+\lambda_{t}+\vartheta_{i t}
$$

elde edilir. Elde edilen bu son eşitliğe, hata bileşenleri modeli (error component model) denir. Burada $\mu_{i}$; bireysel etkieri, $\lambda_{t}$ ise zaman etkilerini gösterir. $\mu_{i_{3}} \lambda_{t}$ ve $\vartheta_{i t} \sim I D\left(0, \sigma^{2}\right)$ (Independent Identically Distributed) yani hata terimlerinin ortalamasının sıfır, varyansının sabit olduğu ve normal dağıldığ (beyaz gürültü sürecine sahip olduğu) varsayılmaktadır.

Panel veri analizinde; önce serilerin durağanlıkları panel birim kök testleriyle incelenmektedir. Sonra bireysel ve zaman etkilerinin türü belirlenmelidir. Açıklayıcı değişkenler arasında, açıklanan değişkenle yakın ilişki içinde olduğu düşünülen ve dolayısıyla içselliğinden şüphelenilen değişken olduğunda, içsellik sınaması yapılmalıdır. Sonrasında model tahmin edilip,

${ }^{2}$ Kodlar için Pamukkale Üniversitesi'nden Doç. Dr. Bülent Güloğlu ve Doç. Dr. Şaban Nazlıoğlu'na teşekkür ederim. 
modelde değişen varyans ve ardışık içsel bağımlılık (otokorelasyon) sorunlarının varlığ 1 test edilmelidir.

\section{Panel Birim Kök Analizi}

Verinin hem zaman hem de yatay kesit boyutuna ilişkin bilgiyi dikkate alan panel birim kök sınamalarının, sadece zaman boyutuyla ilgili bilgiyi göz önüne alan zaman serisi birim kök sınamalarından, istatistiksel anlamda güçlü olduğu kabul edilmektedir (Im, Pesaran ve Shin,1997; Maddala ve Wu, 1999; Taylor ve Sarno, 1998; Levin, Lin ve Chu, 2002; Hadri, 2000; Pesaran, 2006; Beyaert ve Camacho, 2008). Çünkü yatay kesit boyutunun analize eklenmesiyle, verideki değişkenlik artmaktadır.

Panel birim kök sınamasında karşılaşılan ilk sorun, paneli oluşturan yatay kesitlerin birbirinden bağımsız olup olmadıklarıdır. Panel birim kök testleri bu noktada; birinci kuşak ve ikinci kuşak testler olmak üzere ikiye ayrılmaktadır. Birinci kuşak testler de homojen ve heterojen modeller olmak üzere ikiye ayrilmaktadir. Levin, Lin ve Chu (2002), Breitung (2000) ve Hadri (2000) homojen model varsayımına dayanırken; Im, Pesaran ve Shin (2003), Maddala ve Wu (1999), Choi (2001) heterojen model varsayımına dayanmaktadır. Başlıca ikinci kuşak birim kök testleri ise MADF (Taylor ve Sarno, 1998), SURADF (Breuer, Mcknown ve Wallace, 2002), Bai ve Ng (2004) ve CADF'dir (Pesaran, 2006).

$\mathrm{Bu}$ çalışmada, analize dâhil edilen ülkeler homojen olmadığı için, Im, Pesaran ve Shin (2003) (IPS) testi kullanılacaktır. Bu test:

$$
\Delta Y_{i t}=\alpha_{i} Y_{i t-1}+\sum_{j=1}^{p_{j}} \beta_{i j} \Delta Y_{i t-j}+X_{i t}^{*} \delta+\varepsilon_{i t}
$$

modeline dayanmaktadır. Burada $\propto_{i}$; hata düzeltme terimi olup, $\left|\boldsymbol{\propto}_{i}\right|<1$ olduğunda, serinin trend durağan, $\left|\alpha_{i}\right| \geq 1$ olduğunda ise birim köke sahip, yani durağan olmadığı anlaşılmaktadır. IPS testi, $\propto_{\tilde{I}}^{*}$ lerin yatay kesit birimleri için farklılaşmasına, yani heterojen panel yapısına izin vermektedir. Testin hipotezleri:

$\mathrm{H}_{0}: \propto_{i}=1$ bütün yatay kesit birimleri için. Yani seri durağan değildir.

$\mathrm{H}_{1}: \propto_{i}<1$ en az bir yatay kesit birimi için. Yani seri durağandır.

Test sonucunda elde edilen olasıllk değeri 0.05 'ten küçük olduğunda, $\mathrm{H}_{0}$ reddedilmekte ve serilerin durağan olduğuna karar verilmektedir. IPS panel birim kök testi sonuçları, Tablo 4'te yer almaktadır. Tablo 4'teki sonuçlar incelendiğinde, tüm serilerin birinci farkta durağan hale geldikleri görülmektedir. Yani, incelenen dönemde, makroekonomik değişkenlerin durağan olmadıkları ve bu değişkenler üzerine gelen şokların etkisinin, zaman içinde kaybolmadığı görülmüştür. 
Tablo-4: IPS Panel Birim Kök Testi Sonuçları

\begin{tabular}{|c|c|c|c|c|}
\hline Değişken & $\begin{array}{c}\text { Düzey } \\
\text { Değeri }\end{array}$ & $\begin{array}{c}\text { Olasılık } \\
\text { Değeri }\end{array}$ & $\begin{array}{c}\text { Birinci } \\
\text { Farkı }\end{array}$ & $\begin{array}{c}\text { Olasılık } \\
\text { Değeri }\end{array}$ \\
\hline$Y$ & 0.76 & 0.77 & -6.16 & 0.00 \\
\hline$C$ & -0.24 & 0.40 & -8.69 & 0.00 \\
\hline$G$ & 0.53 & 0.70 & -6.22 & 0.00 \\
\hline$X$ & -0.27 & 0.39 & -8.21 & 0.00 \\
\hline$M$ & -1.22 & 0.10 & -6.83 & 0.00 \\
\hline
\end{tabular}

Not: Panel birim kök sınamasında Schwarz kriteri kullanılmış olup, maksimum gecikme uzunluğu 3 alınmıştır. Seriler için test yöntemi olarak, sabitli ve trendli model kullanılmıştır.

$\mathrm{Bu}$ sonuçtan hareketle, son ekonomik krizin, ülkelerin ekonomilerini önemli ölçüde istikrarsızlaştırdığı söylenebilir.

\section{Breush- Pagan Lagrange Multiplier (LM) Testi}

Analizin bu aşamasında, bireysel etkilerin ve zaman etkisinin türünün (rassal veya sabit olduğunun) belirlenmesi amacıyla, LM testi yapılmıştır. Seçilen ülkeler belirli bir ekonomik grubun üyesi olmadığı için, bireysel etkilerin rassal olabileceği, incelenen dönemde ülkelerin büyük kısmını etkileyen bir ekonomik kriz olduğu için zaman etkilerinin de rassal olabileceği öngörülmüştür. Etkilerin gerçekten rassal olup olmadıklarına, LM testi ile karar verilebilmektedir (Baltagi. 2001:15).

$\mathrm{LM}$ testi, $\mathrm{LM}_{1}$ ve $\mathrm{LM}_{2}$ şeklinde ikiye ayrılmaktadır. $\mathrm{LM}=\mathrm{LM}_{1}+\mathrm{LM}_{2}$ 'dir. $\mathrm{LM}_{1}$; bireysel etkilerin rassallığını, $\mathrm{LM}_{2}$ de zaman etkilerinin rassallığını test etmektedir.

$\mathrm{LM}_{1}$ testinde; $\mathrm{H}_{0}: \sigma_{\mu}^{z}=\mathbf{0}$ (Bireysel etkiler yoktur) hipotezi, $\mathrm{LM}_{1}$ istatistiği ile test edilmektedir. $\mathrm{LM}_{1}$ istatistiği, aşağıdaki formülle hesaplanmaktadir.

$$
L M_{1}=\frac{N \cdot T}{2 \cdot(T-1)}\left[\frac{\left.\sum_{i=1}^{N}\left(\sum_{t=1}^{T} \widehat{u}_{i t}\right)\right]^{2}}{\sum_{i=1}^{N} \sum_{t=1}^{T} \widehat{u}_{i t}^{2}}-1\right]^{2}
$$

Burada $\mu$; (4) nolu denklemdeki bireysel etkileri, $N$; yatay kesit (ülke) sayısını, $T$; zaman boyutunu, $\widehat{u}$; (3) nolu denklemdeki hata terimlerinin tahminini ifade etmektedir. Bu test sonucunda elde edilen olasılık değeri, 0.05 'ten küçük olduğunda, $\mathrm{H}_{0}$ reddedilmekte ve bireysel etkilerin rassal olduğuna karar verilmektedir.

$\mathrm{LM}_{2}$ testinde; $\mathrm{H}_{0}: \sigma_{\hat{\lambda}}^{\boldsymbol{2}}=\mathbf{0}$ (Zaman etkileri yoktur) hipotezi, $\mathrm{LM}_{2}$ istatistiği ile test edilmektedir. $\mathrm{LM}_{2}$ istatistiği, aşağıdaki formülle hesaplanmaktadir.

$$
L M_{2}=\frac{N \cdot T}{2 \cdot(N-1)}\left[\frac{\sum_{t=1}^{T}\left(\sum_{n=1}^{T N}\left[\widehat{u}_{i t}\right) \rrbracket^{2}\right.}{\sum_{i=1}^{N} \sum_{t=1}^{T} \widehat{u}_{i t}^{2}}-1\right]^{2}
$$

Burada $\mu$; (4) nolu denklemdeki bireysel etkileri, $N$; yatay kesit (ülke) sayısını, $T$; zaman boyutunu, $\widehat{u}$; (3) nolu denklemdeki hata terimlerinin tahminini 
ifade etmektedir. $\mathrm{Bu}$ test sonucunda elde edilen olasılık değeri, 0.05'ten küçük olduğunda, $\mathrm{H}_{0}$ reddedilir ve zaman etkilerinin rassal olduğuna karar verilmektedir.

$\mathrm{LM}=\mathrm{LM}_{1}+\mathrm{LM}_{2}$ testinde;

$\mathrm{H}_{0}: \sigma_{\mu}^{\mathbf{2}}=\sigma_{\mathrm{\lambda}}^{\mathbf{2}}=\mathbf{0}$ (Bireysel etkiler ve zaman etkileri yoktur)

$\mathrm{H}_{1}: \sigma_{\mu}^{2} \neq 0$ veya $\sigma_{\lambda}^{2} \neq 0$ ya da her ikisi de $\neq 0$ (Etkilerden en az biri ya da ikisi de rassaldir).

Elde edilen olasılık değeri, 0.05'ten küçük olduğunda, $\mathrm{H}_{0}$ reddedilmekte ve etkilerin her ikisinin de rassal olduğuna karar verilmektedir. Bu durumda iki yönlü rassal etki modeli ile tahmin yapılmaktadır. Tablo 5'te LM testlerinin sonuçları yer almaktadır.

Tablo-5: LM Testleri

\begin{tabular}{|c|c|c|}
\hline Test & Olasılık Değeri & Karar \\
\hline $\mathrm{LM}_{1}$ & 0.013 & Bireysel Etkiler Rassaldır. \\
\hline $\mathrm{LM}_{2}$ & 0.275 & Zaman Etkileri Rassal Değildir. \\
\hline $\mathrm{LM}$ & 0.039 & Bireysel Etkiler ve Zaman Etkileri Rassaldır. \\
\hline
\end{tabular}

Tablo 5'teki sonuçlara genel olarak bakıldığında, bireysel etkilerin ve zaman etkilerinin $^{3}$ rassal olduğu görülmektedir. Bu sonuçtan hareketle, tahmin iki yönlü rassal etki modeli ile yapılmıştır.

\section{E. Hausman İcsellik Testi}

Çalışmanın bu aşamasında, bireysel etkilerle açıklayıcı değişkenler arasında ilişki (içsellik problemi) olup olmadığ1, Hausman yöntemi ile test edilmiştir. Testin hipotezleri:

$\mathrm{H}_{0}: \operatorname{Cov}\left(\mu_{1} i, x_{1} i t\right)=0 \quad$ İçsellik problemi yoktur.

$\mathrm{H}_{1}: \operatorname{Cov}\left(\mu_{1} i, x_{1} i t\right) \neq 0 \quad$ İçsellik problemi vardır.

Burada $\mu_{i}$; (4) nolu denklemdeki bireysel etkileri, $X_{i t}$ ise (3) denklemdeki açıklayıcı değişkenleri göstermektedir. Analiz sonucunda elde edilen $\chi^{2}$ (Chi2=Kikare)'nin olasılık değeri 0.05 'ten küçük olduğunda, $\mathrm{H}_{0}$ reddedilmekte ve modelde içsellik probleminin olduğuna karar verilmektedir. İçsellik problemi olduğunda, sabit etkiler modeli kullanılır (Greene, 2003). $\mathrm{H}_{0}$ kabul edildiğinde ise rassal etkiler modeli kullanılmaktadır. Bu tahmin; etkin, sapmasız ve tutarlıdır. Hausman testi, LM testinin bir alternatifi değildir. Ancak, LM testi ile verilen kararın bir sağlaması işlevini de görmektedir.

Hausman testi yapılmış ve Chi2 $=16.82$ ve Chi2 olasılık değeri $=0.542$ bulunmuş olup, bu değer 0.05 'ten büyük olduğu için, $\mathrm{H}_{0}$ hipotezi kabul edilmiş, modelde içsellik sorunun olmadığına karar verilmiştir. Bu durumda, analizin rassal etkiler modeliyle yapılması gerekmektedir ve bu sonuç da LM testi sonuçlarını desteklemektedir.

\footnotetext{
${ }^{3} \mathrm{LM}_{2}$ 'nin olasılık değeri 0.05 'ten büyük olduğu için, zaman etkisinin rassal olmadığ düşünülebilir. $\mathrm{Bu}$ durumda etkinin sabit olup olmadığının F testi ile test edilmesi gerekecektir. Ancak; hem toplam LM testine göre, hem de analiz döneminde ülkeleri genel olarak etkileyen bir faktör (2008 küresel ekonomik krizi) bulunduğu için, zaman etkisinin de rassal olduğuna karar verilmiştir.
} 


\section{F. İki Yönlü Rassal Etkiler Model Tahmini}

Panel veri analizi, iki yönlü rassal etki modeli ile tahmin edilmiş ve elde edilen sonuçlar Tablo 6'da sunulmuştur.

Tablo 6: Tahmin Sonuçları

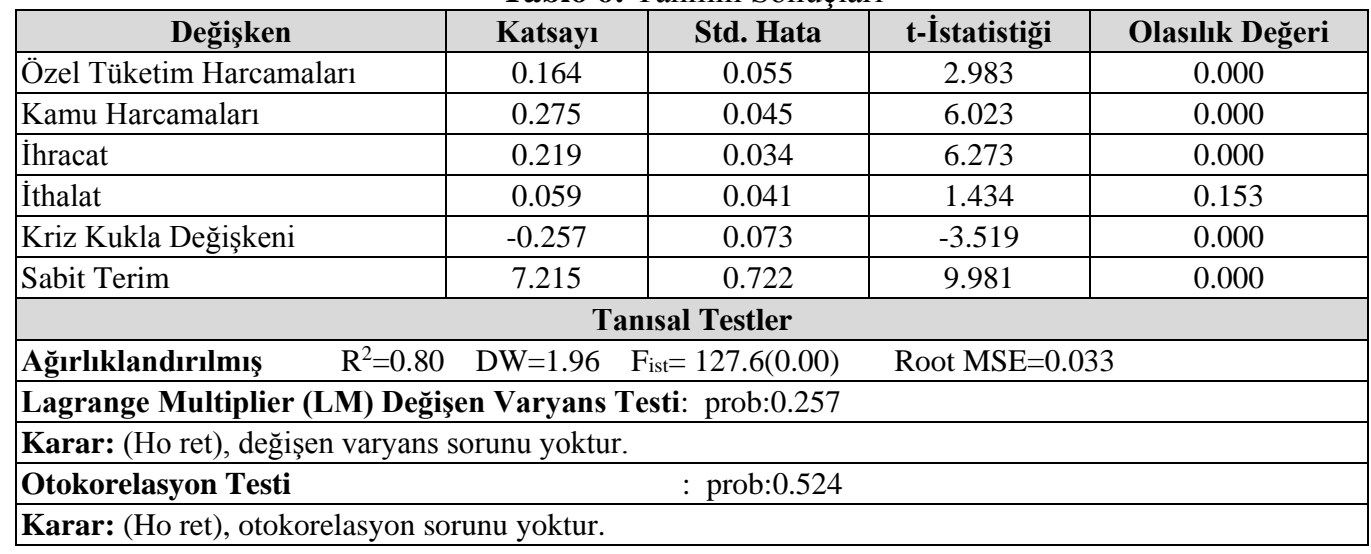

Rassal etki modellerinde, ağırlıklandırılmış istatistik değerleri kullanılmaktadır (Baltagi 2001: 21). Tablo 6'daki ağırlıklandırılmış test istatistiklerine bakıldığında, modelin istatistikî olarak güvenilir olduğu görülmektedir. Ayrıca modelde değişen varyans ve otokorelasyon sorunu olmadığı görüldüğü için, tahmin sonuçları güvenilirdir ve yorumlanabilir.

Tablo 6'daki analiz sonuçları incelendiğinde; ekonomik büyümeyi en güçlü biçimde kamu harcamalarının etkilediği görülmektedir. Kamu harcamalarının ekonomik büyüme üzerindeki etkisi pozitiftir, istatistikî olarak anlamlı ve yorumlanabilir düzeydedir. Kamu harcamalarındaki \%1'lik artış ekonomik büyümeyi \%0.27 arttırmaktadır. Kamu harcamalarında sonra ekonomik büyüme üzerinde en fazla etkiye ihracat ve özel tüketim harcamaları sahiptir. İhracattaki \%1'lik artış ekonomik büyümeyi \%0.21 arttırmakta, özel tüketim harcamalarındaki \%1'lik artış ise ekonomik büyümeyi \%0.16 arttırmaktadır.

1929 krizinde olduğu gibi ülkeler krizden çıkış reçetesi olarak Keynes'in tavsiyelerine uyarak kamu harcamalarını arttırma yoluna gitmiş, krizin etkilerini azaltmak için bazı finans kurumlarını kamulaştırmışlardır. Amerika 850 milyar\$, İngiltere 437 Milyar\$, Rusya 220 Milyar\$, Japonya 118 Milyar\$ kurtarma paketi hazırlamış (Apak, 2009), Çin ise ekonomik büyümesini sürdürebilmek için ulaşım ve altyapı faaliyetlerine kaynak ayırmıştır. Türkiye'de ekonomi yönetimi iç talebi canlandırmak için vergi oranlarını düşürmüş, sosyal güvenlik fonuna ayrıca kaynak ayırarak istihdamın azalmasını engellemek için işçi primlerini bütçeden karşılamıştır.

İhracat ekonomik büyümeyi önemli ölçüde arttırmaktadır. İthalatın etkisi ise düşük kalmıştır. Dış ticaretinin önemli bir kısmını $\mathrm{AB}$ ve Amerika ile yapan Türkiye 2008 krizinde dış talebin düşmesine bağlı olarak, ihracatın ve bunun sonucunda ekonomik büyümenin azalması analiz sonuçlarını destekler niteliktedir. Ekonomilerinin önemli bir kısmı petrol ve doğalgaz ihracatına dayalı 
olan Orta Asya ülkelerinde kriz süresince ihracatı azalmış ve büyüme oranları düşmüştür. 2008 Kriz kuklası değişkenin katsayısı negatif ve istatistikî olarak anlamlıdır. Yani bu kriz, incelenen ülkelerin ekonomik büyümesini negatif yönde ve anlamlı düzeyde etkilemiştir.

\section{SONUÇ VE DEĞERLENDIRME}

Bu çalışmada, 2008 küresel ekonomik krizinin altı Orta Asya ülkeleri ve Türkiye üzerindeki etkileri, 1990-2012 dönemi verileri kullanılarak, panel veri analizi yöntemiyle incelenmiştir. Panel birim kök analizi sonucunda, serilerin durağan olmadıkları yani seriler üzerine gelen şokların etkilerinin zaman içinde kaybolmadığ1, kalıcı olduğu görülmüştür. Panel birim kök analizi sonucunda; krizin ülke ekonomilerini önemli ölçüde etkilediği ifade edilebilir.

Analiz sonucuna göre; ülkelerin ekonomik büyümelerine en çok katkıyı sırasıyla; kamu harcamaları, ihracat ve özel tüketim harcamaları yapmıştır. Büyüme üzerinde en fazla etkinin kamu harcamaları olması tekrar Keynesyen politikaları gündeme getirmiştir. İhracatın ekonomik büyüme üzerindeki etkisi beklendiği gibi yüksek ve istatistikî olarak anlamlı çıkmıştır. Son kriz Türkiye'yi en çok ihracat kanalından etkilemesi bu bulguyu destekler niteliktedir. Türkiye ve Orta Asya ülkelerinin krizlerden en düşük düzeyde etkilenmeleri için ihracat yapılan ülke sayısını arttırmaları gerekmektedir.

Kriz kukla değişkenin katsayısı negatif ve istatistikî olarak anlamlı çıkmıştır. Yani bu kriz, ilgili ülkelerin ekonomik büyümelerini olumsuz yönde ve anlamlı düzeyde etkilemiştir. 2012 Aralık ayında, 2008 krizinden itibaren geçen 4 yıllık süreçte beş $A B$ ülkesinden sonra $A B$ dönem başkanı olan Kıbrıs Rum kesiminin iflasını açıklaması krizin etkilerinin hala devam ettiğinin kanıtı olarak gösterilebilir. Analiz sonuçlarının literatürde yapılan çalışmalarla karşılaştırıldığı zaman; Reinhart ve Rogoff (2008), Weeks (2009), Özdemir ve Göçer (2011), Öztürk ve Gövdere (2011), Hatipler (2011), Gençtürk vd. (2011), Hepaktan ve Çınar (2011), Furceri and Mourougane (2012), Kavcığlu (2012) ve Erol ve Özdemir (2012)'in çalışmalarıyla paralel olduğu, Deveci ve Değirmen (2013) çalışması ile farklılık gösterdiği ifade edilebilir.

\section{KAYNAKÇA}

Apak, S. (2009). "Küresel Kriz ve Türkiye”, Muhasebe ve Finansman Dergisi, 42, 26-39.

Bai J.and Ng S. (2004). "A PANIC Attack on Unit Roots and Cointegration", Econometrica, 72 : 1127-1178.

Baltagi B. H. (2001). Econometric Analysis of Panel Data. (2d ed). New York: John Wiley \& Sons.

Beyaert A. and Camacho M. (2008). "TAR Panel Unit Root Tests And Real Convergence: an Application to the EU Enlargement Process", Review of Development Economics, 12(3): 668-681.

Breuer B., Mcnown R. and Wallace M. (2002). "Series-Specific Unit Root Test With Panel Data", Oxford Bulletin of Economics and Statistics, 64: 527-546.

Breitung J. (2000). "The Local Power of Some Unit Root Tests for Panel Data. in B. Baltagi (ed.), Nonstationary Panels, Panel Cointegration, and Dynamic Panels", Advances in Econometrics, 15: Amsterdam: Jai, 161-178.

Caramazza, F., Rancesco, L. R. and Salgado, R. (2000). "Trade and Financial Contagion in currency Crises", IMF Working Paper, WP/00, http://www.imf.org. 
Choi I. (2001). "Unit Roots Tests For Panel Data", Journal of International Money and Finance, 20: 229-272.

Demirgüç-Kunt, A. and Detragiache, E. (1998). "Determinants of Banking Crises in Developing Countries", IMF Staff Paper, 45(1), http://www.imf.org

Deveci, T. T. ve Değirmen, S. (2013). "İkiz Açık İlişkisi Kriz Öncü Göstergelerini Etkiler mi? 2008 Küresel Kriz Işığında ABD ve Türkiye Analizi”, Anadolu Üniversitesi Sosyal Bilimler Dergisi, 13(2), 1-14.

Eğilmez M. (2009). Küresel Finans Krizi. (5. Basım), Ankara: Remzi Yayıncılık.

Erol, H. Ve Özdemir, A. (2012). "Ekonomik kriz dönemlerinde Türkiye'de uygulanan istihdam politikalarının etkinliği", Amme İdaresi Dergisi, 45(2): 53-79.

Reinhart, C. M. and Felton, A. (2009). "The First Global Financial Crisis of the 21st Century, Part II: Introduction, MPRA Paper No. 13607, http://www.mpra.ub.uni-muenchen.de

Furceri, D. and Mourougane, A. (2012), "The Effect of Financial Crises on Potential Output: New Empirical Evidence From Oecd Countries" Journal of Macroeconomics, 34(3): 822-832.

Galbraith, J. K. (2009). Büyük Kriz 1929, çev. Elif Nihan Akbaş, 1. Basım, İstanbul: Pegasus Yayınları.

Gençtürk M., Dalğar H. ve Yılmaz T. (2011). "Finansal Krizlerin İşletmelerin Finansman Kararlarına Etkileri: İMKB'de İşlem Gören İşletmeler Üzerinde Bir Araştırma", C.Ü. İIBF Dergisi, 12(1): 187-207.

Greene W. H. (2003). Econometric Analysis, (5th Ed). Upper Saddle River, N.J.: Prentice- Hall.

Gujarati D. N. (1999). Basic Econometrics, Mc Graw Hill. (3rd Ed.). İstanbul: Literatür Yayınc1lik.

Hadri K. (2000). "Testing for Stationarity in Heterogenous Panels". Econometrics Journal, 3: 148161.

Hatipoğlu, M. (2011). "Türkiye Ekonomisine Etkileriyle Küresel Finansal Kriz”, Trakya Üniversitesi Sosyal Bilimler Dergisi, 13(2): 191-214.

Hepaktan C. E. ve Çınar S. (2011). "Mali Krizler ve Son Mali Krizin (2008) Reel Sektöre Etkileri”, Dumlupinar Üniversitesi Sosyal Bilimler Dergisi, 30: 155-168.

Im K., Pesaran H. and Shin Y. (1997). "Testing For Unit Roots in Heterogenous Panels". Mimeo, Department of Applied Economics, University of Cambridge.

Im K., Pesaran H. and Shin Y. (2003). "Testing For Unit Roots in Heterogenous Panels". Journal of Econometrics, 115: 53-74.

IMF (2008). World Economic Outlook, April, http://www.imf.org.

IMF. (2009). World Economic Outlook, January, 28.

Kaminsky, L. G. (2000). "Currency and Banking Crises: The Early Warnings of Distress", George Washington University, http://www.gwu.edu.

Kavcıoğlu, Ş. (2012). "Kriz Dönemleri Sonrasında Türk Bankacılık Sektöründe Kredi Analizi (2002-2011 Dönemi)", Finansal Araştırmalar ve Çalışmalar Dergisi, 3(6): 22-39.

Krugman, P. (2010). Bunalım Ekonomisinin Geri Dönüşü ve Küresel Kriz, 6. Basım, İstanbul Literatür Yayıncilık.

Levin A. Lin C. and Chu J. (2002). "Unit Roots Tests in Panel Data: Asymptotic and Finite Sample Properties", Journal of Econometrics, 108: 1: 24.

Maddala G.S and Wu S. (1999). "A Comparative Study of Unit Root Tests with Panel Data and a New Simple Test", Oxford Bulletin of Economics and Statistics, 61: 631-652.

Önder, İ. (2009). "Küresel Kriz ve Türkiye Ekonomisi”, Muhasebe ve Finansman Dergisi, 42, 1225.

Özatay F. (2009). Finansal Krizler ve Türkiye. İstanbul: Doğan Kitap.

Özdemir A. ve Göçer İ. (2011). “Türkiye'de Krizlerin Makroekonomik Değişkenlere Etkileri: VAR Analizi”. Finans Politik \& Ekonomik Yorumlar, 48(560): 57- 72.

Öztürk, S. ve Gövdere B. (2010). "Küresel Finansal Kriz ve Türkiye Ekonomisine Etkileri”, Süleyman Demirel Üniversitesi İktisadi ve İdari Bilimler Fakültesi Dergisi, 2010, 15(1):377-397.

Pesaran, H. (2006). "A Simple Panel Unit Root Test in the Presence of Cross Section Dependence", Cambridge University, Working Paper, No:0346. 
Reinhart, C. R. and Rogoff K. S. (2008). "The Aftermatch of Financial Crisis", American Economic Association, San Fransisco.

http://www.economics.harvard.edu/files/faculty/51_Aftermath.pdf, (26.12.2011).

Rose, A. K. and Spiegel, M. M. (2009), "Cross-Country Causes and Consequences of The 2008 Crisis: Early Warning", Working Paper 15357, http://www.nber.org/papers/w15357

Saxton, J. (2002). "Why Currency Crises Happen", Joint Economic Committee United States Congress, January, http://www.house.gov/jec/

Shiller R.J. (2010). "A Crisis of Understanding",

http://www.projectsyndicate.org/commentary/shiller70/English, (21.12.2011)

Stiglitz J.E. (2008). "The Fruit of Hypocrisy".

http://www.guardian.co.uk/commentisfree/2008/sep/16/economics.wallstreet.global-currency.html (21.12.2011).

Taylor M. and Sarno L. (1998). "The Behaviour of Real Exchange Rates During the Post-Bretton Woods Period", Journal of International Economics. 46: 281-312.

Taylor, J. B. (2009). "The Financial Crisis and The Policy Responses: An Emprical Analysis of What Went Wrong", NBER Working Paper 14631, January, http://www.nber.org

Tong, H. and Wei, S. (2008). "Real Effects of Subprime Mortgage Crisis: Is It a Demand or a Finance Shock?", NBER Working Paper 14205, http://www.nber.org

Weaver, K. (2008). "The Sub-Prime Mortgage Crisis: A Synopsis, Global Securitisation and structured Finance", Deutsche Bank.

Weeks J. (2009). "The Impact of The Global Financial Crisis on The Economy of Sierra Leone. A Report For UNDP Freetown and the Ministry of Finance and Economic Development". Republic of Sierra Leone. Country Study. 18, September.

$\mathrm{Xu}, H$. and Hamori, S. (2012), "Dynamic Linkages of Stock Prices Between The BRICs and The United States: Effects of The 2008-09 Financial Crisis", Journal of Asian Economics, 23(4): 344-352.

Yay, T., Yay, G. G. ve Yılmaz, E. (2001), "Küreselleşme Sürecinde Finansal Krizler ve Finansal Düzenlemeler", İstanbul Ticaret Odas1, Yayın No:2001-47.

Yeldan, E. (2008). “Avrupa'da Bir Hayalet Dolaş1yor”, Ekonomi Politik, http://www.bilkent.edu.tr. www.cnnturk.com/2012/ekonomi/dunya/12/06/rumlar.iflas.bayragini.cekti/687544.0/index.html, (12.11.2012)

www.dunya.com/eco_index.php, $(06.10 .2012)$

www.adb.org, (14.03.2012)

www.worldbank.org, (14.03.2012)

www.unctad.org, (04.10.2012) 